\title{
IS Strategic Plan for Higher Education Based on COBIT Assessment: A Case Study
}

\author{
Harwikarya, Mujiono Sadikin, Devi Fitrianah, Mohammad Mustofa Sarinanto, Ida Nurhaida, and Arif R. \\ Dwiyanto
}

\begin{abstract}
As the guidance and direction of IS/IT Operation in each organization, IS Strategic Plan plays the very important role in Higher Education. Many IS projects fail since there was no adequate IS planning. The paper presents study results of IS strategic plan formulation for higher education institution. The stages of IS strategy formulation are performed based on Ward \& Peppard framework and utilize COBIT 4.1 IS Management guidance. IS strategic plan formulated in this study consist of some components such: application portfolio based on McFarlan matrix, IS architecture, and IS/IT action stages recommendation.
\end{abstract}

Index Terms-COBIT, higher education institution, IS strategic plan, IT governance.

\section{INTRODUCTION}

Nowadays, information system and information technology are becoming critical role player for any organization to achieve its goals and become a winner in this globalization and competition era. For higher education, IS/IT plays as the most important aspect in supporting its process of education, research, administration, and community services [1]. Unfortunately, there are so many IS/IT project implementations failure. Masticola [2] described that one of the main causes of information systems project getting fail is because of lack of adequate planning. The importance of IT Strategic Planning is also underlined by Mc Gee R [3].

Based on the importance of IS strategic plan as described in the above section and as one of some recommendacions proposed by the previous study [4], this paper presents the study results of formulation of IS strategic plan for higher education as a case study. The objective of this study is to capture the IS direction and IS management in a higher education institution.

The IS strategic plan framework and staging that is utilized in this study is Ward \& Peppard [5] and TI governance guidance of COBIT 4.1 by ISACA [5].

The rest of this paper is organized as follows: section two

Manuscript received March 31, 2014; revised June 20, 2014. This study was supported by The Competency Research Grant from the Higher Education Directorate General, Ministry of Education of Indonesia second year of 2013.

Harwikarya, Devi Fitrianah, Ida Nurhaida, Mujiono Sadikin, and Arif Rifai Doni are with Mercu Buana University, JKT Indonesia (corresponding author: Mujiono Sadikin; e-mail: harwikarya.hardi@mercubuana.ac.id, devi.fitrianah@mercubuana.ac.id,_ｉda.nurhaida@mercubuana.ac.id, mujiono.sadikin@mercubuana.ac.id, arifrifai@mercubuana.ac.id).

Muhammad Mustofa Sarinanto is with Indonesia Financial Transaction Reports and Analysis, Indonesia (e-mail: mustafa.sarinanto@ppatk.go.id). will describe a related study regarding to IS strategic plan framework, brief of COBIT 4.1 framework, and a brief of the University of Mercu Buana as well; the methods and tools of the study presented in the section three; in the section four, it will be elaborated result of each stage in the IS strategic plan formulation; and the last section present conclusion of this IS strategic planning study and also the action plan recommended.

\section{RELATED STUDY}

\section{A. IT Governance (ITG)}

ITG allows an organization to fully exploit the benefits of the existence of the information held, and with the maximization of benefit, capitalize on opportunities, gain advantage in competition. ITG is a structure of relationships and processes that are used to direct and control an organization to achieve goals that are set, to provide more value and to keep the balance between risks and returns of IT and processes related to IT. There are five aspects to which the management concern in directing and controlling their IT: strategic alignment, value delivery, risk management, resources management and performance management[6].

\section{B. IS/IT Strategics Plan Framework}

There are some frameworks have been proposed to perform IS strategic plan. Some of them are: Ward \& Peppard, James Martin - IBM, Value Chain - Michael Porter, and Critical Success Factor as is resumed in [7]. The modification of Ward \& Peppard method which is adjusted for Indonesian Ministry and Government bodies is proposed by Mujiono[8]. The other framework is proposed by Kani et.al which is stated as RBV (Resources-Based View). The RBV framework investigates and proposes a relationship between organization IS capabilities with IS strategic planning. The most recent methode is proposed by [9], [10] which consist of 5 phases: alignment IT with business; analysis of performance capability;IS strategic planning formulation; IT Tactical planning; and Socialization and closing. With their variations, there are some commons phase in IS strategic formulation. These common phases are: assessment and alignment with corporate governance such vision, mission, corporate strategic and program; analysis of internal and external component regarding to business and IT matter, IS strategic formulation, evaluation and documentation. In this study, we use Ward \& Peppard as a main framework that is assumed that it is as suitable for Higher Education institution.

\section{COBIT® Framework}


The framework is based on generic IT Activities. Summarized from[11], COBIT categorizes IT activities in a generic process model within four domains. These domains are Plan and Organize (PO), Acquire and Implement (AI), Deliver and Support (DS), and Monitor and Evaluate (ME). The domains map of IT traditional responsibility areas of plan, build, run and monitor. There are 34 generics activities across those four domains. The PO domain consists 10 activities numbered from PO1 to PO10, AI domain consists 7 activities ranging from $\mathrm{AI} 1$ to AI7, DS domain consists of 13 activities identified by DS1 to DS13 and ME domain consist of 4 activities identified by ME1 to ME4.

\section{University of Mercu Buana}

Situated in Jakarta, Indonesia as a central campus, University of Mercu Buana (www.mercubuana.ac.id) is a continuously growing private own university. The university serves six faculties which consist of one degree, 16 bachelor degrees, 6 postgraduate degrees, and one special program. Currently, the education processes serve more than 22 thousand students from all degree, and all of those educational services are served by around one thousand lectures and around 550 education staffs. There are 4 others separated campuses which located around of Jakarta City.

The main IT processes are used to serve the core university activities in education and researches. The other process support various general purposes such: finance, human resources, and communication - collaboration as well. In serving of all of IT services, the management, operation, and support are handled by two subdivisions. The first subdivision is the center of information system development whose main responsibility is to develop and operational support of system, application, and the second one is the center of network and internet infrastructure whose the main responsibilities are any support related to network infrastructure, hardware and internet connection. A few studies related to university IS/IT have been performed. One of those studies is as explained in [12] which discuss the evaluation of IT University management and operation.

\section{Methods AND ToOLS}

\section{A. Method}

The briefly steps which are done to perform the IS strategic plan in this study are: preparation, IT Governance assessment which results some recommendation, and IS strategic plan formulation. The order of those stepping are illustrated in Fig 1. The preparation and IT Governance assessment has been performed by using the COBIT 4.1 Self Assessment tools and its results are presented in [4]. Thus, this study is the continuity of the previous study. The main activities of this study are: to perform an analysis of any data and evidence collected from survey stage and to formulate the IS strategic plan. In the analysis stage, we used Critical Success Factor [7] and Activities Chain Analysis[8] as the tools. While in the IS strategic formulation we adobt Ward \& Peppard framework and to described the application portfolio that we proposed it is used the Mc Farlan matrix as explained in [13]. The COBIT framework of IT related domain process is utilized as a tool to guide the formulation of IS/IT managament roadmap and recommendation.

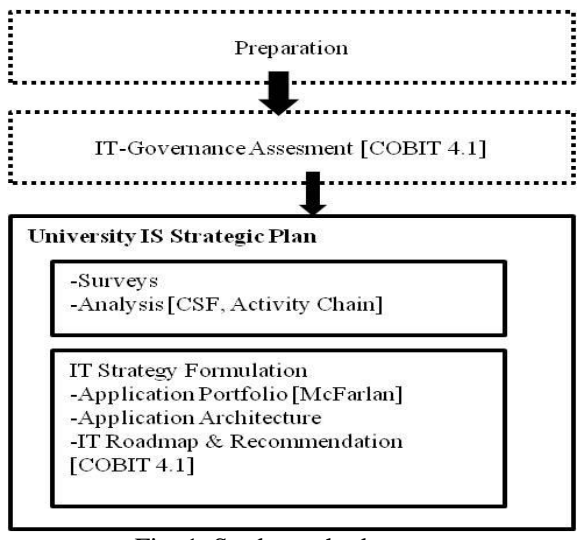

Fig. 1. Study method stages.

\section{B. IS/IT Strategic Plan Framework}

This study uses Ward \& Peppard framework to assess the current situation and to formulate the future direction of University IT. The global Ward \& Peppard framework is illustrated as the Fig. 2 [13]. The framework consist of two main steps: analysis as an input and formulation as an output. The first step, identification and analysis are performed for internal and external environment include both business and IS/IT components.

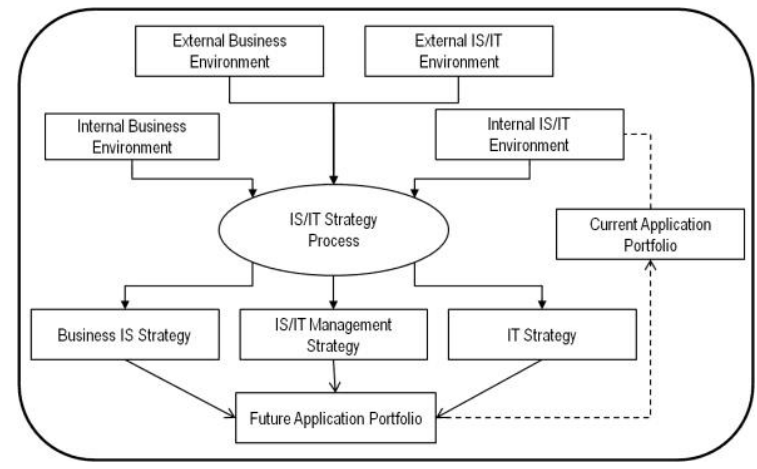

Fig. 2. Ward \& Peppard IS/IS strategic plan Frameworks.

- Identification and analysis of internal business environment include various aspects such: business strategy, organization goal and target, internal resources, internal business / service processes, organizational culture, and the role and policy.

- The aspects which are included in the external business environment such: organizational competitiveness, market situations, competitor, business situations, socioeconomical aspects, political aspects, etc.

- Some aspects as internal IS/IT are: current condition of IS/IT, IS/IT contributions to the organization, supporting resources, technology infrastructure, software and data, and the current of application portfolio as well.

- Identification and analysis of external IS/IS are performed for: the growth of information technology, opportunity and challenging in its utilization for organization, condition of third parties IS/IT such supplier, competitor, and market.

The second step is the process to formulate IS/IS strategic planning. This step delivers three main results as follow:

- Information System Business Strategy, which consists of: 
the needs of IS/IT support for each organizational unit or division to assist them in achieving their goals and targets, application architecture and their interrelationship, and how the application architecture is planned.

- Information Technology Strategy, which consists of the strategy and policy in maintaining the information technology infrastructure and human resources who support those technologies.

- Strategy of SI / TI Management includes managing of IS/T elements performed by organization to assure that all process and results achieved are in line with all policies and parameters determined before.

\section{RESULTS AND DisCUSSIONS}

\section{A. Analysis}

\section{1) Process business analysis}

In this study, we used activity chain analysis as a tool for analyzing university's internal process business and external environment such regulation, competitors, etc. as used in [7] to perform internal analysis of university business process and services process. This tool is also proposed by Taura [14] as a model of designing and production of a certain product which is executed globally. The objective of the activity chain analysis is to assure the history of related information between one process to another. This activity chain is summarized Fig. 3. All activities within the university are classified into two major groups: core activities and supporting activities. Core activities are the activities that distinguish one industry to another industry. Included in the core activity, the main activities in the organization as higher education institution regarding to government regulation are to do enrollment, to perform research and to serve the public or citizen as implementation of citizen social responsibility. One of the differences with the state university is that in private university there is a marketing activity. The supporting activities are common activities in all industries such: logistics \& procurement, human resources, financial, public relation \& secretary, and physical infrastructure management as well.

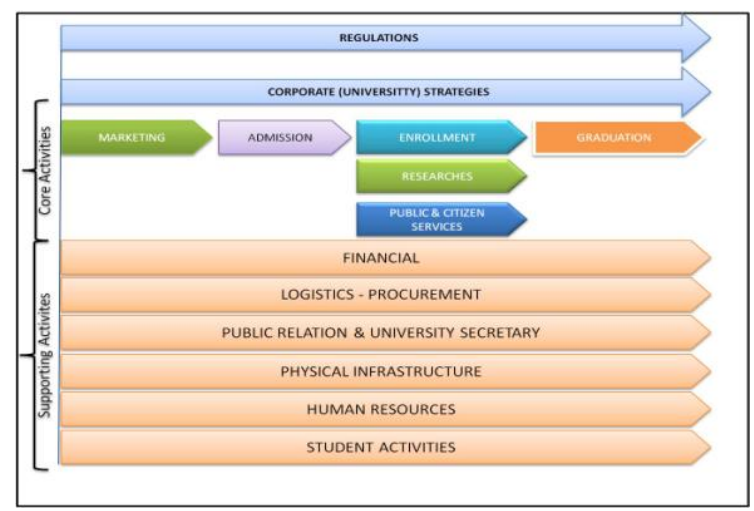

Fig. 3. University's activities chain.

\section{2) IS applications}

Two main information system applications that support main university activities are academic information system and e-learning system. The first one is the system which is used to support academic and enrollment process such: admission, lecture and class scheduling, enrollment, examination, grading, and graduation. The second one is the application that is used for distance learning purposes since the university has implemented an electronic learning since 2006. There are some less important information system such: university portal, reporting application, etc.

\section{3) IS/IT management}

The IS/IT management in supporting university activities is represented by two divisions which are under the directorate of resources. Those two subdivisions are the center of networking and internet stated as PJI (Pusat Jaringan Internet) and the center of information system development, stated as PPSI (Pusat Pengembangan Sistem Informasi). The fist division responsibilities are to manage and maintain hardware and network infrastructure while the second division responsibilities are to develop, manage, and operate information system applications. Both of divisions are supported by 16 IT human resources with various skill levels ranging from analyst, programmer, to technical support staff.

\section{B. IS Strategic Plan Formulation}

The IS strategic plan formulation consist of: application portfolio, application architecture, and IS/IT recommendation.

\section{1) Application portfolio}

The application portfolio performed as Mc Farlan Matrikx[13] is described as Fig. 4. As the Mc Farlan matrix guidance, the system applications of certain entrprise can be categorized in to four quadrants depend on its impartance or priority levels. Due the space limitation, there are not all of application proposed in this study can be listed in this fiugure. Those application are part of the Key operational quadrant that actually consist of 27 system applications.

\begin{tabular}{|c|c|}
\hline Strategic & High Potential \\
\hline $\begin{array}{l}\text { 1. University Portal } \\
\text { 2. University Career } \\
\text { 3. Alumna } \\
\text { 4. BORANG simulation } \\
\text { 5. Modul Corporate } \\
\text { Dashboard }\end{array}$ & $\begin{array}{l}\text { 1. Student candidate } \\
\text { mapping } \\
\text { 2. Alumni market demand } \\
\text { mapping }\end{array}$ \\
\hline $\begin{array}{l}\text { 1. Online and integrate } \\
\text { admission-enrollment } \\
\text { 2. Online library } \\
\text { 3. .....the others } 25 \\
\text { applications }\end{array}$ & $\begin{array}{l}\text { 1. Intranet portal } \\
\text { 2. University mail }\end{array}$ \\
\hline Key Operational & Support \\
\hline
\end{tabular}

Fig. 4. University's portfolio application.

\section{2) IS architecture}

The IS architecture proposed in this study is summarized as Fig. 5. Overall system applications are combination of existing (operated) application, application in current developing, and applications purposed in the future based on user requirements, regulation comply requests or other technical reasons. There are sevent main system applications to support daily business operastions which each of them consists of some modules. Those main applications are surounded and integrated with others supporting applications. The overall system will include five main databases: student, 
curricula, human resources, building-facilities and finance.

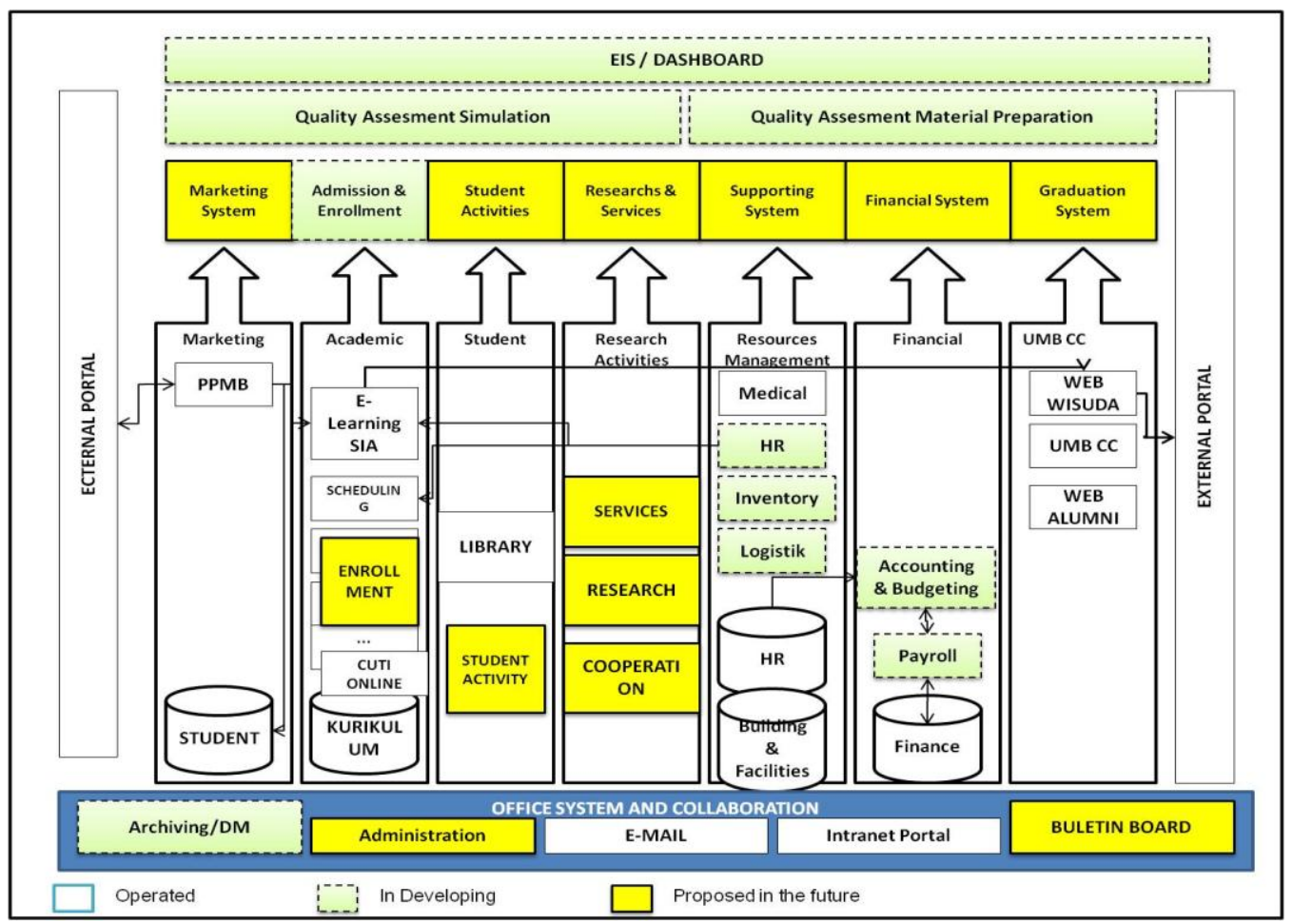

Fig. 5. University’s global system architecture.

\section{3) IT recommendation}

Based on the assessment result which is performed in the previous study [4], since the capability level of University Mercu Buana IT processes is in the first stage of its development, this study proposes a short term action plan need to be performed. Those initial action proposal recommended to be taken in the first five years includes:

\section{4) Critical problem solving}

We have identified and propose for some critical problem such: Data inconsistency, data inaccuracy; difficulties in system operation, un-balancing of information system requirement and capabilities; limitations of IT infrastructures; and IT staff lacks.

Data inconsistency and data inaccuracy are the major problem so it is very important to be solved at the first time. For this reason we present our detail proposal in this section as below.

Proposed Solutions :

1) Clarity of data custodian / data owner, and consolidation of existing data

2) Access authority role : UMB has to make a clear decision regarding this role. The clarity of data owner will play the significant role in responsibilities, audit trail, and storage efficiency. Based on the assessment, the data custodian authorities can be proposed as Table I below:

\section{5) Information system strategy}

For the information system strategy we propose some action can be taken in the first five years: re-development of admission and enrollment application system, the speedup of digital library development; the development of borang application system; and the speedup of various application development which currently is being developed such: inventory system, finance and budgeting, and HR information system.

TABLE I: DATA / PROCESS CUSTODIAN RECOMMENDATION

\begin{tabular}{|c|c|}
\hline Data/Process & Custodian \\
\hline Admission & Marketing Unit \\
\hline Student Data & Academical Unit \\
\hline Curricula Data & \\
\hline Course Material & Course Material Center \\
\hline Staff \& Lecturer & Human Resources Unit \\
\hline Enrollment & Center \\
\hline Activities & \\
\hline Standard \& SOP & SPMI (Internal Auditor) \\
\hline Research & $\begin{array}{l}\text { PUSLIT \& P2M (Research \& Services } \\
\text { Center) }\end{array}$ \\
\hline Library Collection & Library Department \\
\hline Alumni & UMB TC \\
\hline Student Activity & Directorate of Kemahasiswaan \\
\hline Finance & Financial Unit \\
\hline $\begin{array}{l}\text { Logistics \& } \\
\text { Inventory }\end{array}$ & Biro MGS \\
\hline
\end{tabular}

Redevelopment of existing system application to support admission and enrollment is an urgent task must be executed soon because many reasons. The system application is a main tool to support university core business and all of the university's units depend on this application for their daily operational and decision making as well. But, according to the analysis and fact finding in survey stakes, it is contrary that the system application has been absolutely in its technology, supporting feature, or even its capabilities. The system has been operated since 2006, mean it was almost 7 years ago.

\section{6) Information technology strategy}

Regarding to this information technology component we proposed some a program to implement the green computing and green data center, which consists of: the usage of UPS 
with efficiency up to $97 \%$, server virtualization, storage data center, consolidation of server data and storage, and the usage of energy management feature in each CPU

\section{7) IS management}

University's IS/IT has become a critical aspect to support the execution of education, research, administration, community service processes and to fulfill the compliant to government regulation. It is one of the main reasons to improve the managemenet of University's IS/IT. The managemenet of University's IS/IT which is separated by infrastructure - software and hardware infrastructure - as current condition is not the right one and it is not the common best practices which is explained in [6]. Based on the fact finding and interview with user in the survey stages, there are some problems arise caused by this miss-management, such as the unclear who will be as responsible party regarding to some mall function to certain user system. With some addition reasons, the study propose to restructure the IS/IT management. The main proposal solutions is to establish a new directorate which its position is in executive management level. Adobt the IT related domain process by COBIT, the new organization is illustrated in the diagram as Fig. 6. The new organization is performed base on function or process as: Planning \& Organizing (PO), Acquisition and Implementation (AI), Delivery Services (DS), and Monitoring \& Evaluation (ME).

The mapping of each division/sub divisions task with COBIT domain processes is described in Fig. 7 with note: Executive Committe: Rector, Vice Rector, Director; R: Responsible, A: Accountable, C: Consulted, I: Informed

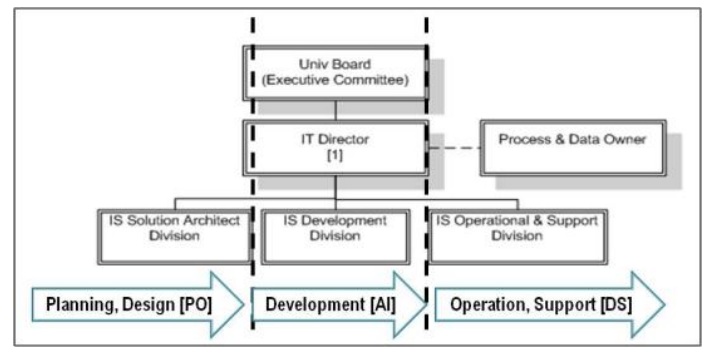

Fig. 6. University’s IT organization.

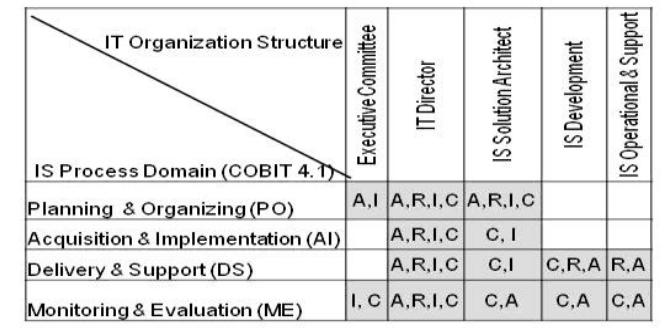

Fig. 7. Organization structure VS COBIT domain processes

\section{CONCLUSION AND RECOMMENDATION}

As the execution of one of the recomendation performed by the ITG assessment previous study, this study presents the IS strategic plan for higher education instituion. The study shows how the modification of familiar framework of IS strategic plan and IT Governance framework able to guide the University's IS/IT direction and management. However the study results still contain some shortcoming such: there is no assesment to users side and its implication that there is no recommendation for users performed yet. As some examples of user side assessment are: their IT literate, their attitude in using of the IT tools, their awareness in IT security, data privacy or piracy as well and so on. In the future study we will investigte such those aspects since all of those aspects influence much for IS/IT management and operation.

\section{REFERENCES}

[1] CRUE, "Governance of information technology in higher education Spain: Spanish Association of University Rectors," CRUE, 2009.

[2] S. P. Masticola, "A simple estimate of the cost of software project failures and the breakeven effectiveness of project risk management," in Proc. 2007 First International Workshop on the Economics of Software and Computation, 2007, p. 6.

[3] R. Mcgee, "Information technology (IT) strategic planning for libraries," Libr. Mabagement, vol. 27, no. 6/7, pp. 470-485, 2006.

[4] M. Sadikin, H. Hardi, and W. H. Haji, "IT governance self assessment in higher education Based on COBIT case study: University of Mercu Buana," J. Adv. Manag. Sci., vol. 2, no. 1, pp. 83-87, 2014.

[5] ISACA, CISA Review Manual 2010, December, Rolling Meadows, IL, 2010, pp. 21-60.

[6] ISACA, CISA Review Manual 2010. Rolling Meadows, IL 60008 USA: ISACA, 2010

[7] L. P. Gates, "Strategic planning with critical success factors and future scenarios: An integrated strategic planning framework," 2010.

[8] Mujiono, "Perancangan strategis sistem dan teknologi informasi kementerian / lembaga," Seminar Nasional Manajemen Teknologi XV, 2012, pp. 1-11.

[9] P. Henrique, D. S. Bermejo, A. O. Tonelli, A. L. Zambalde, J. De Brito, and J. L. Todesco, "Implementation of information technology (IT) governance through IT strategic planning," African J. Bus. Manag., vol. 6, no. November, pp. 11179-11189, 2012.

[10] P. Henrique and D. S. Bermejo, "Planning and implementing IT governance in Brazilian public organizations," in Proc. The 44th Hawaii International Conference on System Science, 2011, pp. 1-10.

[11] IT Governance Institute, COBIT 4.1 Framework, Control Objective, Management Guidelines, Maturity Models, Rolling Meadows, IL 60008 USA: ITGI, 2007.

[12] D. Fitrianah, "Audit Teknologi Informasi Dengan Kerangka Kerja COBIT Untuk Evaluasi Manajemen Teknologi Informasi di Universitas XYZ," Universitas Indonesia, 2007.

[13] J. Ward and J. Peppard, "Strategic planning for information system," 3rd ed., New York: Wiley, 2002, pp. 43-44.

[14] T. Taura, Y. Aoki, K. Kawashima, S. Komeda, and H. Ikeda, "A proposal of the activity chain model and its application to global design Toshiharu Taura Yasukazu Aoki Hiroshi Takada Koji Kawashima Shinji Komeda Hajime Ikeda Jun Numata Proposal of the 'Activity Chain Model,", Tokyo, 1995.

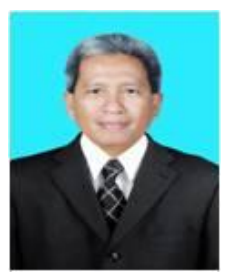

Harwikarya was born in Jakarta, Indonesia, on July $14^{\text {th }}$ 1958. He holds a bachelor degree in instrumentation physics, University of Indonesia Jakarta in 1983. He is a specialist program in informatics and electronics. He received his master degree in control engineering, University of Indonesia Jakarta in 1998, doctor degree in computer science, University of Indonesia Jakarta in 2009. His research interest include image processing, control system, and IT master plant.

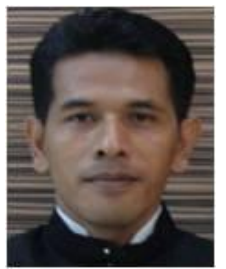

Mujiono Sadikin was born in Magetan, East Java, Indonesia, on December $6^{\text {th }} 1970$. He holds a bachelor degree in informatics from Bandung Institut of Techonoloy, Bandung, Indonesia. His master degree is also held in the same field, the same institution as well. Currently he is a doctoral student in computer science, University of Indonesia. $\mathrm{He}$ also holds CISA certification since 2011. Some of his experiences are: As a team leader in IT Governance an Procedure preparation of Directorate Land \& Transportations Ministery of Transportation, team leader of IT Audit and Assessment University of Mercu Buana, and some more. Since 2012 he leads the University of Mercu Buana IT Directorate as the director. 